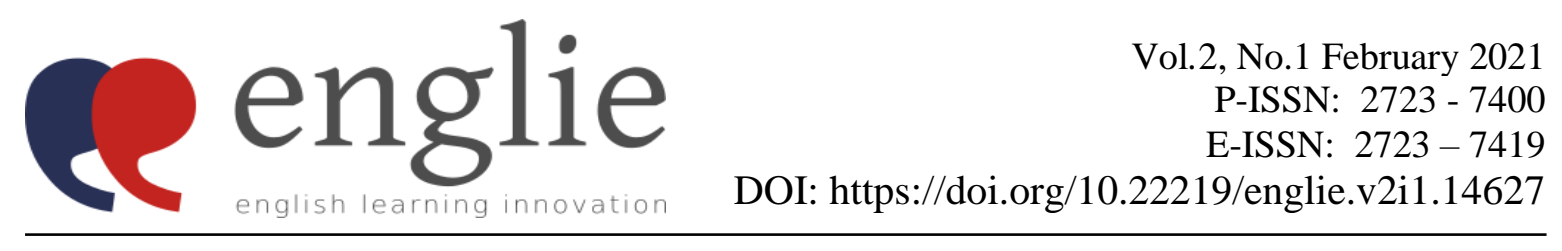

\title{
Postmodernism Creates Innovative English Teaching Learning by Utilizing ICT
}

\author{
Yustin Dwi Rahmawati \\ Post Graduate, Yogyakarta State University, Yogyakarta, Indonesia \\ Corresponding Author: yustin.dwi.rahmawati@gmail.com
}

\begin{abstract}
Through comprehensive literature review and an examination of both Postmodernism and ICT, it is proposed that the influences of ICT have acted and continued to act to promote Postmodernism. The development of ICT is utilized by education field for teaching learning process. Many teachers and students utilize the existing of ICT as model of teaching and learning especially English. This study discussed about teachers' belief and students' belief in using ICT to have innovative English teaching learning. Qualitative descriptive was used in this study. The data was collected by conducting the interview. The participants were five English teachers and five students that chose randomly. The result showed that both teachers' and students' belief in using ICT is to make English teaching learning easier, more interesting, and effective.
\end{abstract}

Keywords: Postmodernism, ICT, teachers' belief, students' belief

\section{INTRODUCTION}

Postmodernism is complex, multi-faceted and plural. Tarnas (1991) says 'the postmodern mind may be viewed as an open-ended, indeterminate set of attitudes that has been shaped by a great diversity of intellectual and cultural currents. The spread and crossproliferation of information and knowledge presents the individual with endless choices as well as the potential for vastly differing but equally effective solutions to problems. This influence of increased choice highlights ICT's role as an agent of empowerment and emancipation. Coyne (1998) maintains that the Internet and other computerized communications networks have the potential to free us from hierarchical structures, allow for individual expression, and expression, enable the ultimate definition of our individual and collective humanity'. Postmodernism is above all else a social phenomenon and the result of the continued evolution of the Western mind.

Through that capabilities that ICT offers, undreamed height of scientific and technological progress has been reached in an amazingly short span of time. Information and Communication Technology (ICT) could be regarded as an agent of Postmodernism. Nowadays, ICT becomes the role in teaching learning process, especially for teaching English. Many teachers or lecturers utilize ICT for teaching and learning. So, it can be said that it is one of postmodernism contribution to the education. However, some teachers still do no use ICT for teaching. 
According to Bull and Ma in Ahmadi (2018), technology provides unlimited resources to language learners. It is also supported by Harmer (2007) and Gençlter (2015) that teachers should encourage learners to find appropriate activities through using computer technology in order to be successful in language learning. Then, the using of ICT is based on the teacher belief. The successful of teaching learning is based on the teachers' belief. Similarly, Ismail, Almekhlafi, and Al-Mekhlafy (2010) investigated teachers' perceptions of the use of technology in teaching languages in UAE schools. They studied both Arabic and English teachers' ICT perceptions. Results showed the importance of the role of teachers' ICT perceptions in first and second language teaching and learning. Results also indicated that teachers confirmed the inevitable impact of technology on their own teaching practices which promote students' language learning. Here, this study would like to investigate the teachers' belief and students' belief in using ICT to have innovative English teaching learning.

\section{Literature Review}

\section{Postmodern and ICT}

Elaati (2016) stated that the Postmodernism is to undermine Western metaphysics, and the destruction of the central arguments that dominated ancient and modern Western thought, such as language, identity, origin, voice, and mind, so has used the mechanisms of dispersal, uncertainty, disagreement and westernization. Postmodernism appeared combined with the philosophy of anarchy, nihilism, disassembly, meaninglessness and disorder; therefore, it got some of its characteristic from those philosophies.

The concept of "postmodern" was associated with a wide range of the different meanings. It could designate a chronological period, a particular style found in some contemporary artwork and literary text, a property of structures at the end of the twentieth century, as an historical period.

Postmodernism has appeared firstly in the field of painting, architecture and civil engineering, before moving to philosophy, literature, art, technology, and the rest of the humanities and knowledge. Postmodernism theory has invaded all the disciplines, such as literature, criticism, art, philosophy, ethics, education, sociology, anthropology, science and culture, economics, politics, and architecture (Carter, 2012)

Conlon (2000) believes that ICT provides functionalities that are core to the Postmodernism idea. These functionalities include the distribution and enablement of the global economy, the storage and dissemination of information via databases, the changing of the workplace and rise of the information worker, the speeding up and optimization of social as well as professional life, an increase in the ability to communicate and the creation of virtual worlds on the Internet.

According to the Banukhrisma and Danashree (2017), some areas of science and technology stands out with much more visible innovations that have variously generated enormous enthusiasm and utopian hopes or evoked deep-seated anxieties and rejection. In the second of the twentieth century, three of the areas around which search hopes and fears crystallized were information and communication technologies, biotechnological, and ecology. Each of these areas has also come to be associated with ideas about the legacies of modernity in particular ways, and therefore illuminates some facets of post modernism in its relation to science and technology.

The rise of digital technology was accompanied by the utopian hopes for the transformation of social structures. It was claimed that marginalized individuals and 
communities would be empowered by easier and cheaper access to information, that the new medium would enable the greater democratization of political process, and that it would transform, education and allow new types of social communities to emerge. At the same time, it become clear that, while digital technology provided easy access to the most varied sources of knowledge, it also made it difficult to International Journal of Multidisciplinary Research and Development distinguish accurate from inaccurate information, or statement that had been arrived at through some sort of expert review process from those that were simply expressions of opinion. Education via digital technology, it turned out, would require good deal more tutoring to addresses these problems then had initially been assumed. While information had been a scarce resource throughout most of history the internet was triggering on information explosion.

\section{The use of ICT in teaching English}

Nowadays, ICT has a role in teaching English as foreign language. According to Mayls (2016), with a blossoming of the ICT as a new tool in language teaching, EFL teachers and methodologist are expected to adopt a new view of integrating basic ICT skills in EFL classroom appropriately. Language is a very complex and teachers should teach the complexity of the language in easy and simple way. Dewi (2017) states that Information and Communication Technology (ITC) can be applied in teaching and learning language. It is line with Florish (2014) that ICT has the potential important role in supporting and enhancing of learning language. It means that ICT is very helpful for the language learners. Most students enjoy and use internet, television, radio, YouTube, or another mobile learning, especially for learning English. ICT can play a crucial role in development of language or second language. The classroom will be more flexible and communicative by using ICT. Teachers are able to find many ways to engage students' motivation to learn English with ICT. Kirschner (2012) concludes that "Technology provides ways for great teachers to refresh their own scholarship and pedagogy and bridges the gap between how our students experience their college curriculum and how they learn everything else"

Constructivist learning theory indicates the role of ICTs as active construction of new knowledge based on a learner's prior experience. Hence, learning is an active process affected by the ICT tools used by teachers during the instruction. Constructivism Theory is a good fit for working towards establishing well-equipped teachers with meaningful ICT usage so they can ensure learning among learners. Constructivism focuses on the importance of a gradual knowledge construction built by the teacher using different ICT skills and tools. This trend was also supported by research conducted by Harman and Koohang (2005), and Hung and Nichani (2002) who focused on the importance of steady knowledge building where ICT teachers' ability saves time and effort. Other theories such as Media Richness theory (Daft \& Lengel, 1984; 1986; Trevino, Lengel, \& Daft, 1987) also highlighted the importance of using ICT for facilitating the teaching and learning situations. Almekhlafi (2017) argues that media represented by ICT competency on the teachers' part takes a crucial role in learning provided that teachers use the appropriate media to enable effective learning to take place. Since most of the learning takes place via communication, the ICT tool facilitates a shared understanding between the teacher and the learners and among the learners themselves. 


\section{The Students' and the teachers' belief in using ICT}

Teachers' beliefs refer to teachers' pedagogic beliefs or those beliefs of relevance to an individual's teaching (Calderhead 1996). Lortie (1975) proposed that teachers' beliefs originate either from their personal experiences as students, or from their personal life experiences such as family traditions, values, social interaction, community participation, and so forth. As stated by Khader (2012) in Gilakjani (2017), beliefs are defined as the teachers' arguments and their views on teaching and learning. Beliefs are made slowly over time. In the context of technology use in the classroom, it means that teacher beliefs and attitudes influence teachers' use of computers in the classroom (Ertmer \& Hruskocy, 1999; Marcinkiewicz, 1994; Tearle, 2004), and there is a relationship between teachers' beliefs and their instructional decisions (Haney, Czerniak, \& Lumpe, 1996; Mumtaz, 2000). Veen (1993), for example, found that teachers are more likely to adopt new technology if they can use it in accordance with their existing beliefs and practices.

Furthermore, the teachers with student-centered pedagogical beliefs, who adopt studentoriented constructivist teaching, are successful at integrating technology except in cases where anxiety about computers prevented them from appropriating the technology. Furthermore, this discrepancy in beliefs was affirmed in a study conducted by Chen (2008), who noted the influence of external factors, as well as the additional factor of possessing a limited or misconstrued understanding of constructivist practices. However, he asserted that these factors did not act as independent agents, but rather, it was the "interplay among these factors" that creates the divergence between what teachers believe about technology and what they implement in their classrooms.

If it is seen from students' perspective, Jimenez (2014) agrees that students really believe that technology becomes an effective teaching aid. English language learners realize that by using technology they will improve the main skills and the sub-skills. This study demonstrates that students feel that technology is necessary to learn the target language faster.

\section{METHOD}

The study of teachers' beliefs and students' belief in using ICT for English teaching learning used qualitative research because here the researcher only described the teachers' and students' belief in using ICT to create innovative English teaching learning. To collect the data, the researcher conducted the interview. The interview was a open ended interview or in-depth interview in which the interviewers wanted to know the data in detail but efficiently and formally. This research has 10 participants that consist of 5 English teachers and 5 students that chose randomly.

\section{FINDINGS AND DISCUSSION}

\section{Teacher' belief in using ICT for teaching English}

After conducting the interview, the researcher found that the participants (English educators) used ICT for teaching learning English. They belief that the usage of ICT was very important to support the teaching learning. There are many kinds of ICT used that belong to both internets based and without internet connection. The ICT used that belong to internet based were Canva, Prezi, Padlet, Kahoot, Edmodo, Schoology, google scholar Storyboard, Moodle, University Learning Management System (LSM), Text to Speech, Audacity, Genially 
and Voky. Besides, the ICT used that belong to without internet connection were Slide Presentation (Ms. Power Point), Ms. Office, and Ms. Excel. In choosing the ICT, participant had their own consideration for example, they choose ICT that were free, assessable, and suitable with lesson objective or the topic. It is line with Veen (1993) found that teachers are more likely to adopt new technology if they can use it in accordance with their existing beliefs and practices. Almekhlafi (2017) argues that media represented by ICT competency on the teachers' part takes a crucial role in learning provided that teachers use the appropriate media to enable effective learning to take place. So, the teachers used ICT based on their consideration that were really able to support the teaching learning process. The ICT used must be appropriate with the topic given to the students.

All participant proposed the similar reason for using ICT in teaching learning that are to make the teaching learning more interesting, simple, and to follow the lifestyle that everything utilized the ICT. (Daft \& Lengel, 1984; 1986; Trevino, Lengel, \& Daft, 1987) also highlighted the importance of using ICT for facilitating the teaching and learning situations. The using of ICT did really support the teaching learning process. Meanwhile, in using ICT for teaching learning, the participants found some advantages and disadvantages. The advantages are the teaching learning became more interesting, students could be more active and creative, it could facilitate all the students with different learning style. However, it also had disadvantages that were it took time for the teachers for preparation. Then, the teachers also had some challenges in using ICT such as: teacher had to be creative and competent in using ICT, teacher had to be patient in giving tutorial for the students how to use the ICT because not all the students were familiar with the ICT used.

From the students' side, the researcher found that participants believed that the using of technology in teaching learning was very important, interesting and really helpful. It is supported by Jimenez (2014) that students really believe that technology becomes an effective teaching aid. Kinds of ICT that participant (students) used were various that consist of both internet based and without internet connection such as: power point, kahoot, canva, elsa, and genially. It is line with Rey (2013) that it gives a chance for students to get in touch with different kinds of media. Integration of ICT necessitates deciding on the use of different ICTs in each skill, the types of ICT applications to be used, planning the favorite activities, managing problems arising from the activities planned, and so on. By using or mastering many ICTs, it can dig students' creativity. Meanwhile, the participants argued that those ICTs were not replaced the teachers' role and position. The students still needed the teacher to explain the material in detail. It was line with Greenberg, Raphael, Keller, \& Tobias, 1998), views on student learning and the meaning of "good teaching," as well as perceptions concerning the role of ICT in student lives (Windschitl \& Sahl, 2002; Zhao, Pugh, \& Sheldon, 2002). It showed us that the teachers' role could not be replaced by ICT. The students found some advantages and disadvantages. The advantages are the teaching learning process became interactive and interesting. By using ICT, it could create students' creativity. For the disadvantages, it was quite difficult for the students that were not familiar with the ICT used and sometime, the facility of school or college did not really support for example, the connection was not really good and LCD did not work well.

\section{CONCLUSION}

Postmodern brings innovative though that can create sophisticated ICT in which this ICT can be utilized by English teacher during teaching learning process. Both teachers and students believe that the using of ICT can create the interesting and effective teaching learning process. 
It can give innovative and effective way in teaching. ICT can be regarded as a new model of teaching and learning. For the teacher, teaching using ICT gives the challenge, advantage, and also disadvantage but overall, it can create the active, innovative, and effective classroom activity and it depends on how the teachers' belief in using ICT. For the students, learning language through ICT challenges the students to be aware about ICT and build their creativity. ICT also provides easy and simple way for them to learn language.

\section{REFERENCES}

Almekhlafi, A. (2006). The effect of Computer-Assisted Language Learning (CALL) on United Arab Emirates EFL school students' achievement and attitude. Journal of Interactive Learning Research, 17(2), 121-142.

Almekhlafi, A. G., \& Almeqdadi, F. A. (2010). Teachers' perceptions of technology integration in the United Arab Emirates school classrooms. Educational Technology \& Society, 13(1), 165-175.

Carter, D. (2012). Literary theory. UK: Oldcastle Books.

Conlon, T. (2000). Visions of change: Information technology, education and postmodernism. British Journal of Educational Technology, 31 (2), 109-116.

Coyne, R. (1998). Cyberspace and Heidegger's pragmatics. Information Technology and People, 11 (4), 338-350.

Floris, F. D. (2014). Using information and communication technology (ICT) to enhance language teaching \& learning: An interview with Dr. S. Gumawang Jati. TEFLIN Journal. 25,139-146.

Harman, K., \& Koohang, A. (2005). Discussion board: A learning object. Interdisciplinary Journal of E-Learning and Learning Objects, 1(1), 67-77.

Martha, G. C. (2013). Teachers' beliefs and practices in technology-based classrooms: A developmental view. Journal of Research on Technology in Education, 39(2), 157181.

Rey. (2013). Teachers' Beliefs and the Integration of Technology in the EFL Class. Bogotá, Colombia. Pages: 51-72

Shifflet, R. \& Weilbacher, G. (2015). Teacher beliefs and their influence on technology use: A case study. Contemporary Issues in Technology and Teacher Education, 15(3), 368394.

Tarnas, R. (1991). The passion of the Western mind: Understanding the ideas that have shaped our world view. London: Random House. 